\title{
Sifting disease-causing signal from genomic noise
}

\author{
Daniel G MacArthur ${ }^{1,2}$ \\ From Beyond the Genome 2012 \\ Boston, MA, USA. 27-29 September 2012
}

Recent advances in DNA sequencing technology are transforming our understanding of the genetic basis of rare human diseases. It is now possible to rapidly and costeffectively interrogate the majority of protein-coding bases in the human genome (known collectively as the exome), finding mutations that would have been difficult if not impossible to discover with the traditional approaches of linkage and candidate gene sequencing.

However, unambiguously identifying the disease-causing mutations in a patient's exome remains challenging. Next-generation sequencing, while powerful, still requires careful filtering to remove errors and is underpowered for discovery of larger insertions/deletions (indels) and complex variants; coverage of genes is incomplete due to biases in DNA capture and sequencing; and predicting the likely functional impact of observed variants is still an immature science. Importantly, existing catalogues both of "normal" variation in reference populations and of reported diseasecausing mutations are incomplete and biased. Finally, methods for communicating the results of large-scale sequencing to key target audiences - clinicians, patients and researchers from other fields - remain poorly developed.

In this presentation I describe recent advances in variant-calling from next-generation sequencing technology, and their application to exome data from over 15,000 individuals from multiple different disease-specific studies. Functional annotation of sequence variants across these large samples illustrates the surprising degree of putatively functional genetic variation even in apparently healthy individuals. However, the existence of a very large and accurately called reference panel of exomes provides a powerful resource for interpreting the probability of disease causation for variants observed in rare disease samples. I also discuss new approaches to analyzing and presenting the results from family-based studies of protein-coding mutations in rare disease patients.

${ }^{1}$ Analytic and Translational Genetics Unit, Massachusetts General Hospital, Boston, MA 02114, USA

Full list of author information is available at the end of the article
Author details

'Analytic and Translational Genetics Unit, Massachusetts General Hospital, Boston, MA 02114, USA. ${ }^{2}$ Broad Institute of Harvard and MIT, Cambridge, MA 02142, USA.

Published: 1 October 2012

doi:10.1186/1753-6561-6-S6-08

Cite this article as: MacArthur: Sifting disease-causing signal from genomic noise. BMC Proceedings 2012 6(Suppl 6):08.
Submit your next manuscript to BioMed Central and take full advantage of:

- Convenient online submission

- Thorough peer review

- No space constraints or color figure charges

- Immediate publication on acceptance

- Inclusion in PubMed, CAS, Scopus and Google Scholar

- Research which is freely available for redistribution
() Bïomed Central
C Biomed Central

ㄷ 2012 MacArthur; licensee BioMed Central Ltd. This is an Open Access article distributed under the terms of the Creative Commons Attribution License (http://creativecommons.org/licenses/by/2.0), which permits unrestricted use, distribution, and reproduction in any medium, provided the original work is properly cited. 